\title{
THE GASTRIC SECRETION IN EXOPHTHALMIC GOITRE AND MYXOEDEMA
}

\author{
By J. LERMAN AND J. H. MEANS
}

(From the Thyroid Clinic and Metabolism Laboratory of the Massachusetts General Hospital, Boston)

(Received for publication August 13, 1931)

Our knowledge of the gastric secretion in endocrine disturbances is limited, and this applies to exophthalmic goitre and myxoedema as well as to other endocrine conditions. In both the old and recent literature one finds conflicting statements regarding the gastric contents in thyroid disease. King (1) states that in exophthalmic goitre there may be a complete cessation of secretion of hydrochloric acid resulting in practically an achylia gastrica, and the good results obtained from acid therapy and dietary regulations are sometimes striking. Lockwood (2) studied the gastric contents of 24 patients with hyperthyroidism who had digestive complaints and found 10 or $\mathbf{4 1 . 6}$ per cent showed no free hydrochloric acid, 3 low acid and 11 normal acid. Similarly Moll and Scott (3), in a series of 34 patients with definite exophthalmic goitre, found 19 (56 per cent) with achlorhydria, 10 with hypochlorhydria, 4 with normal acid and 1 with high acid. Herzfeld (4) obtained the following results in 22 cases: achlorhydria and hypoacidity 15 , normal acidity 4 , and increased acidity 3. Keefer and Bloomfield (5) mention 30 per cent as the incidence of achlorhydria in hyperthyroidism. In a series of 21 cases Moore (6) found achlorhydria in 76 per cent.

On the other hand Neilson (7) considered hyperacidity as one of the early signs of beginning hyperthyroidism. Lewit (8) reported that thyroidin given subcutaneously or by mouth resulted in an increase in the acidity of the gastric secretion in the majority ( 69 per cent) of 26 patients examined. Badylkes (9), feeding desiccated thyroid, found a depression of the gastric secretion. Boenheim (10), investigating 8 patients, found no characteristic gastric secretion in exophthalmic goitre. Finally Lewit (8), summarizing the contradictory results found in the European literature on this subject, came to the conclusion that the gastric secretion varied with the severity of the disease. In 10 cases of classical Graves' disease he found 5 with no free hydrochloric acid, 4 with low acidity and 1 with normal acidity. In 6 cases of mild hyperthyroidism - "Basedowismus"-hyperacidity was the rule, and in 11 cases of "forme fruste" normal acidity prevailed. 
The same confusion exists in the reports on the gastric secretion in myxoedema and hypothyroidism. In 1920, Katz (11) cited cases with low thyroid function and hyperacidity relieved by thyroid. More recently Levy (12) found hyperacidity in all but one of 10 cases of hypothyroidism. In 2 cases which he considered to be myxoedema, ${ }^{1}$ thyroid medication depressed the acidity. In agreement with these results is the statement of Hutton (13) that hypothyroidism is associated with a high incidence of peptic ulcer.

On the other hand, Boenheim (10) observed achlorhydria in the 3 patients studied by him. In two of these, gastric acidity became normal after thyroid medication. Sturgis (14) reported the results of the gastric analyses of 5 cases of myxoedema. Three showed no free hydrochloric acid in fasting contents and a low total acidity following the test meal; one showed normal acid; and one low acid in both fasting and test meal samples. Lockwood (2) also reported on 10 cases of myxoedema and found achlorhydria in 60 per cent.

The experimental data in this subject are also contradictory. In 1916 Hardt (15) demonstrated that in dogs with Pawlow pouches large doses of thyroid by mouth depressed the gastric secretion. Truesdell (16), working in the same laboratory, confirmed this result. A year later, Chang and Sloan (17) showed that this is true also when dogs are fed small doses of thyroid. After thyroidectomy they found a marked rise in the volume of the gastric secretion as well as a rise in gastric acidity.

On the other hand, Rogers, Rahe and Ablahadian (18) showed that alkaline saline solutions or alcohol extracts of thyroid administered subcutaneously caused a vigorous stimulation of the gastric secretion. Lewit (8) confirmed this partly in that he found that intravenous thyroidin in dogs resulted in an increase in the volume of gastric secretion, but no change in the acidity. He also cited the work of Ponirowski to the effect that thyroidectomy diminishes the secretion of gastric juice and thyroid subcutaneously increases it.

A general criticism may be applied to all the results obtained by the above investigators, particularly those who dealt with the incidence of achlorhydria in thyroid disease, namely, that the gastric juice was obtained by means of test meals and not histamine. It is now well recog-. nized that true achlorhydria cannot be diagnosed with any certainty unless the gastrice juice is obtained by means of a maximum stimulation as with histamine. We have been unable to find any reports in the literature on the gastric contents in patients with thyroid disease obtained by this means. This study was, therefore, carried out in an attempt to obtain

1 The following metabolic data given in the text throw doubt on this diagnosis: Case 8 . Basal metabolic rate -20 before treatment, -25 after treatment. Case. 9. Basal metabolic rate -20 before treatment, and -16 after treatment. 
definite knowledge of the gastric secretion in exophthalmic goitre and in myxoedema, using histamine as the main stimulus for the secretion of gastric juice.

\section{METHOD}

The technique of obtaining the gastric contents is described in another paper dealing with the gastric analysis in normal people (19). Briefly, it consists in the analysis of three samples of gastric contents, i.e., the fasting contents, and the samples obtained one-half hour and one hour after the subcutaneous injection of $0.5 \mathrm{mgm}$. ergamine acid phosphate (histamine) and the ingestion of $50 \mathrm{cc}$. of a 7 per cent alcoholic solution. The volume, the free and total acidity of each sample were recorded, using Töpfer's reagent and phenolphthalein as the indicators in the titration of the respective acidities. The results were compared with normals and correlated with various factors. The method of obtaining the normal data is described in the paper referred to above. The analyses were done by various members of the resident medical staff.

\section{MATERIAL}

\section{Exophthalmic goitre}

A total of 50 patients with exophthalmic goitre had gastric analyses done by the method described. Almost all the patients were in the age groups of 20-59, only one below 20 and one over 59 years of age. The majority of patients were under 40 years of age. There were 18 males and 32 females. The results for free and total acidity in relation to age of patients are tabulated in Table I. This, as well as the subsequent tables, is based on the maximum acidity of the gastric juice following stimulation with histamine and alcohol.

The striking result is the high incidence of anacidity-38 per cent for the group. The incidence of anacidity in 200 normal patients (19) examined the same way was found to be 13 per cent. The result becomes all the more significant if the comparison is made with those patients falling into the same age groups as our exophthalmic goitre patients, and a correction applied for the difference in age distribution. This has been done in Figure 1. It shows that the corrected incidence of anacidity in exophthalmic goitre is 45.6 per cent compared to the normal of 12.6 per cent. This chart also shows that hypoacidity is higher in the exophthalmic goitre group than in the normal, whereas hyperacidity is much lower. The results for total acidity run more or less parallel with those for free acidity. The correction for sex distribution as compared to the normals is omitted because it does not alter the results significantly.

The relatively low acidity of the gastric secretion in exophthalmic goitre patients can be demonstrated in another way by comparing their average acidities with those of the normals according to age groups. This is done graphically in Figures 2 and 3 . In general, normal people secrete 
almost twice as much acid in the stomach as patients with exophthalmic goitre, the actual values being $40.4 \mathrm{cc}$. and $21.0 \mathrm{cc}$. respectively.

It has been shown by Bloomfield and Keefer (20) that physical fitness affects the degree of gastric acidity. We divided our patients on the basis of their general physical condition into good, fair and poor-at best an approximation. There was apparently no correlation between physical fitness and gastric acidity in these cases. The average free acidity of the 29 patients in good condition was $20.7 \mathrm{cc}$. N/10 per $100 \mathrm{cc}$. and of the
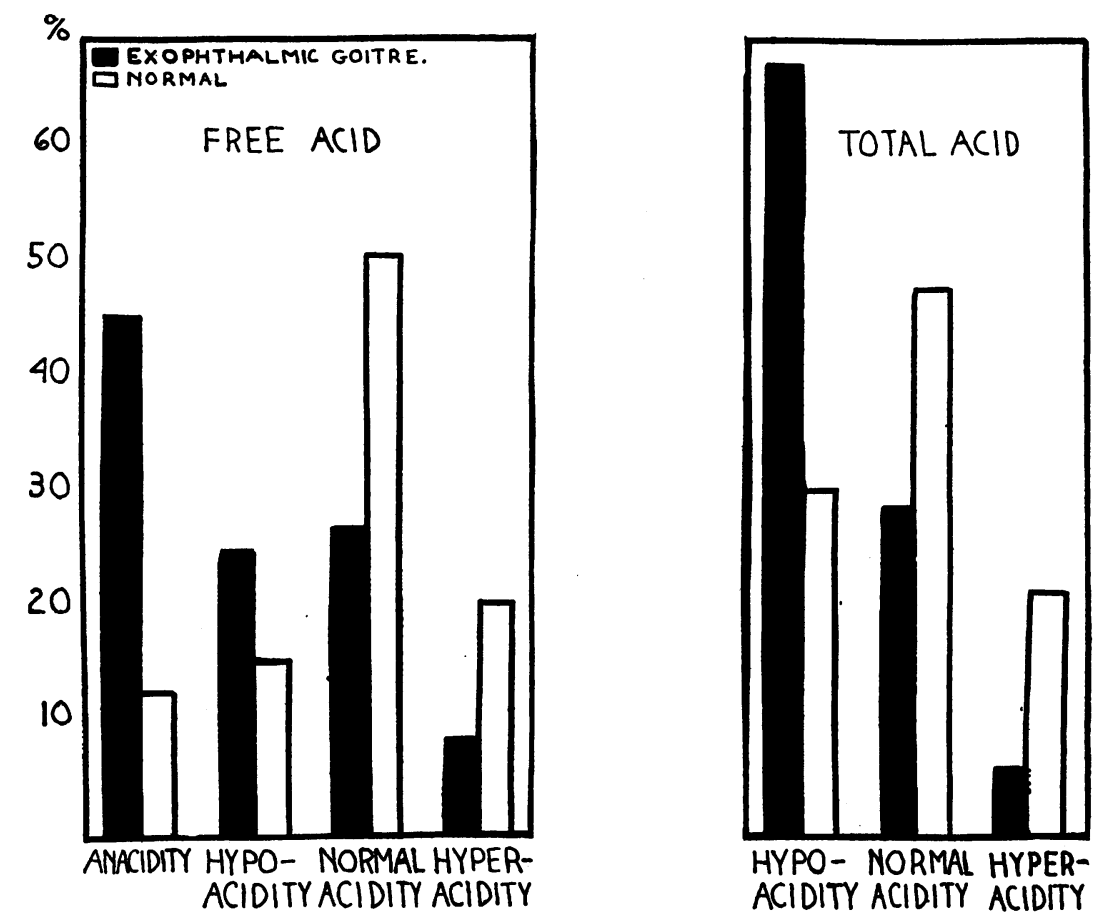

Fig. 1. The Percentage Incidence of the Various Degrees of Acidity of 159 Normal Patients Under 60 Years of Age and of 50 Patients with Exophthalmic Goitre, Corrected for Differences in Age DisTRIBUTION.

19 patients in fair condition $23.1 \mathrm{cc}$. N/10 per $100 \mathrm{cc}$. The two patients found to be in poor condition may be disregarded. Since the probable errors of these averages are between two and three, it is obvious that these averages do not differ by any significant amount.

Bloomfield and Keefer (20), as well as other writers, stress the relationship between age and degree of gastric acidity. An analysis of Table I and Figures 2 and 3 shows that in exophthalmic goitre, at least, this is not definite. For example, the coefficient of correlation between age and free acidity is $-0.21 \pm 0.091$, a figure which must be interpreted with 
caution. The apparent slight correlation is entirely due to the cases without free hydrochloric acid. The cases possessing any amount of free acidity show no correlation with age.

We have also analyzed our data with respect to the relationship of acidity to the level of the red blood cell count, the hemoglobin, and the basal metabolic rate before iodine medication. The results here also indicate that these factors are not definitely related to the degree of gastric acidity, except in the case of achlorhydria to be discussed below. For example, of the 12 patients with hypochlorhydria (free acid) none had

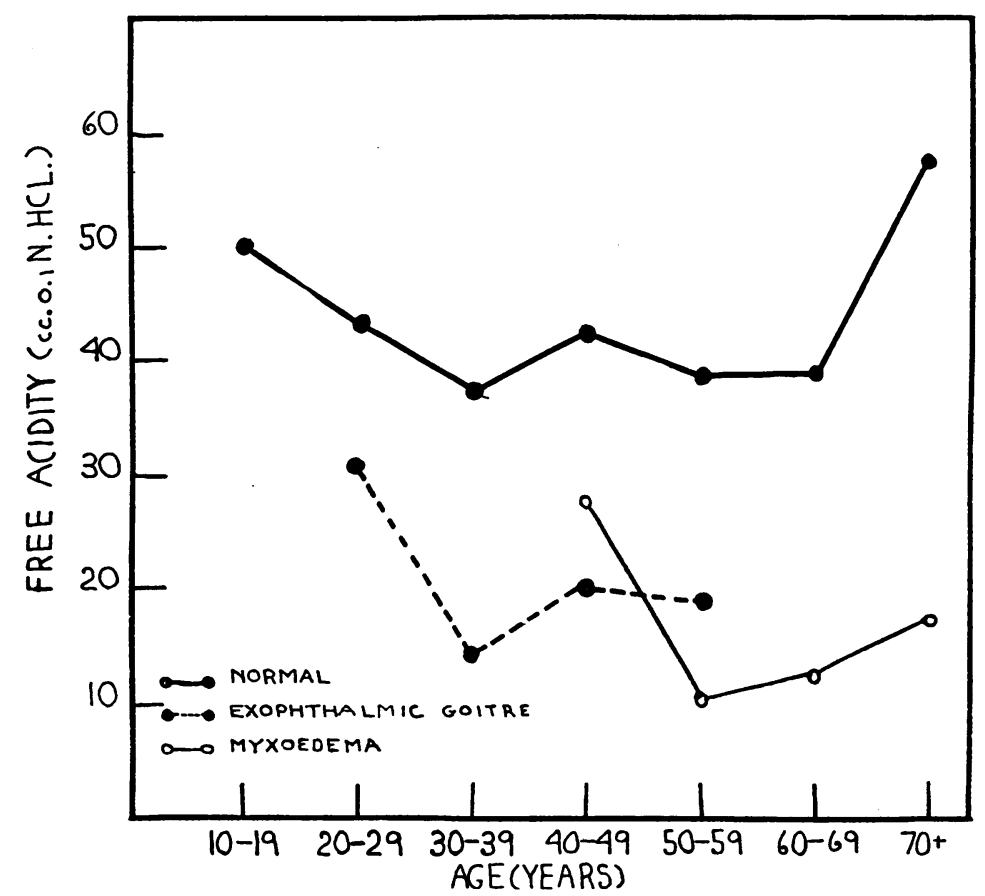

Fig. 2. The Average Free Acidity by Age Groups of 200 Normal Patients, 50 with Exophthalmic Goitre and 17 with Myxoedema

a red count below 4.5 million and only one had a hemoglobin below 70 per cent. Of the 15 with normal acidity, 3 had a red count below 4.5 million and none a hemoglobin below 70 per cent. The corresponding figures for the 4 patients with hyperchlorhydria were one and two respectively.

Another way of expressing the relationship is to calculate the coeffcients of correlation. Between the acidity and the red blood cell count the values are $+0.0002 \pm 0.095$ for free acid and $+0.018 \pm 0.100$ for total acid; between the acidity and the hemoglobin they are $+0.29 \pm$ 0.087 and $+0.22 \pm 0.091$ for free and total acid, respectively. The 
former show no degree of correlation whatever, the latter show a slight degree which, however, disappears when the achlorhydria cases are separated from the main group.

The data for the relationship between the acidity of the gastric juice and the height of the metabolism are given in Table II. The coefficients of correlation are $-0.27 \pm 0.088$ for free acidity and $-0.29 \pm 0.087$ for total acidity. As a result of the scattered distribution, these figures are not highly significant. Nevertheless, they indicate a probable inverse relationship between the level of metabolism and gastric acidity. As

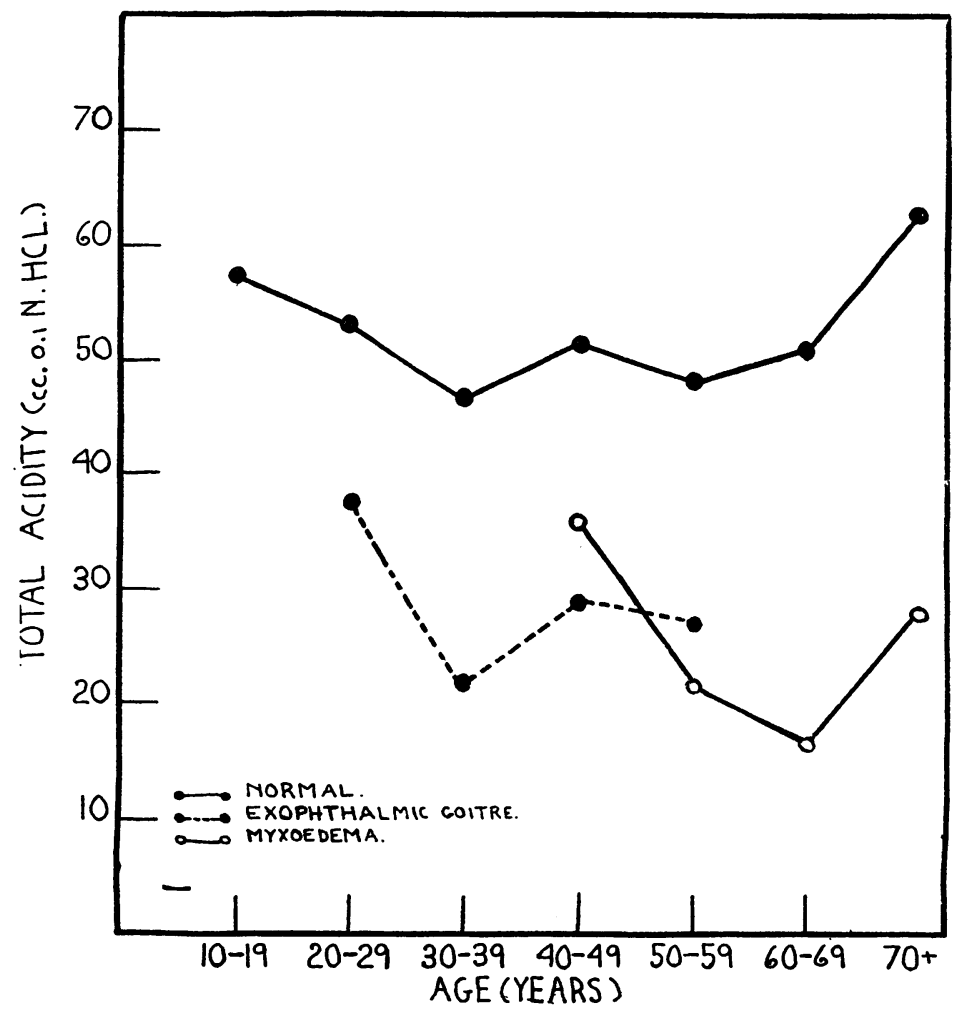

Fig. 3. The Average Total Acidity by Age Groups of 200 Normal Patients, 50 with Exophthalmic Goitre and 16 with Myxoedema

judged from the averages of Table II, this relationship is not a progressive one. There is a sudden change at the 50-59 interval of metabolism, but not much variation before and after it. Again, if the cases with anacidity are separated out, it is found that the remainder show no correlation between acidity and level of metabolism, and all the averages have similar values. Thus, the coefficient for the 31 cases with free acid is $-0.08 \pm$ 0.122 , which is smaller than its probable error. 
TABLE I

Distribution by age of the free and total acidity of 50 patients with exophthalmic goitre

\begin{tabular}{|c|c|c|c|c|c|c|c|c|c|c|}
\hline & \multicolumn{5}{|c|}{ Free acidity } & \multicolumn{5}{|c|}{ Total acidity } \\
\hline \multirow[t]{2}{*}{ Cc. $0.1 \mathrm{~N} \mathrm{HCl}$} & \multicolumn{4}{|c|}{ Age (years) } & \multirow{2}{*}{ Total } & \multicolumn{4}{|c|}{ Age (years) } & \multirow{2}{*}{ Total } \\
\hline & -29 & $30-39$ & $40-49$ & $50+$ & & -29 & $30-39$ & $40-49$ & $50+$ & \\
\hline 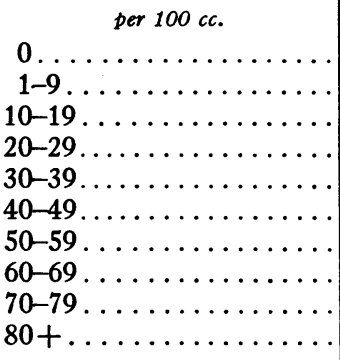 & $\begin{array}{c}\text { cases } \\
2 \\
1 \\
4 \\
1 \\
1 \\
2 \\
2 \\
\\
2\end{array}$ & $\begin{array}{c}\text { cases } \\
9 \\
2 \\
2 \\
1 \\
1 \\
1 \\
2\end{array}$ & $\begin{array}{c}\text { cases } \\
5 \\
1\end{array}$ & $\begin{array}{c}\text { cases } \\
3 \\
2\end{array}$ & $\begin{array}{c}\text { cases } \\
19 \\
5 \\
7 \\
2 \\
5 \\
4 \\
2 \\
2 \\
3 \\
1\end{array}$ & $\begin{array}{l}\text { cases } \\
\\
3 \\
1 \\
3 \\
1 \\
2 \\
2 \\
1 \\
1 \\
1\end{array}$ & $\begin{array}{l}8 \\
3 \\
2 \\
2 \\
1\end{array}$ & $\begin{array}{c}\text { cases } \\
1 \\
3 \\
2 \\
\\
1 \\
1 \\
1 \\
1\end{array}$ & $\begin{array}{c}\text { cases } \\
2 \\
3 \\
1\end{array}$ & $\begin{array}{c}\text { cases } \\
1 \\
16 \\
7 \\
7 \\
4 \\
4 \\
3 \\
2 \\
3 \\
3\end{array}$ \\
\hline Total............... & 15 & 18 & 10 & 7 & 50 & 15 & 18 & 10 & 7 & 50 \\
\hline Averages..... & 30.7 & 14.2 & 20.3 & 19.0 & & 37.5 & 21.7 & 28.9 & 26.9 & \\
\hline \multicolumn{6}{|c|}{ Standard deviation of acidity $=24.1$} & \multicolumn{5}{|c|}{$\begin{array}{l}\text { Standard deviation of acidity } \\
\quad=26.6 \\
\text { Standard deviation of age } \\
=10.5\end{array}$} \\
\hline
\end{tabular}

TABLE II

Distribution according to level of metabolism of the free and total acidity of 50 patients with exophthalmic goitre

\begin{tabular}{|c|c|c|c|c|c|c|c|c|c|c|c|c|c|c|}
\hline \multirow{3}{*}{$\underset{\mathrm{HCl}}{\mathrm{Cc.1}} \mathrm{N}$} & \multicolumn{14}{|c|}{ Basal metabolic rate (per cent) } \\
\hline & \multicolumn{7}{|c|}{ Free acidity } & \multicolumn{7}{|c|}{ Total acidity } \\
\hline & -30 & $30-39$ & $40-49$ & $50-59$ & $60-69$ & $70+$ & $\begin{array}{l}\text { To- } \\
\text { tal }\end{array}$ & -30 & $30-39$ & $40-49$ & $50-59$ & $60-69$ & $70+$ & $\begin{array}{l}\text { To- } \\
\text { tal }\end{array}$ \\
\hline $\begin{array}{l}\text { per } 100 \text { cc. } \\
0 \ldots \ldots \\
1-9 \ldots \ldots \\
10-19 \ldots \\
20-29 \ldots \\
30-39 \ldots \\
40-49 \ldots \\
50-59 \ldots \\
60-69 \ldots \\
70-79 \ldots \\
80+\ldots \ldots \\
\end{array}$ & $\begin{array}{c}\text { cases } \\
1 \\
1 \\
1 \\
1 \\
2 \\
1\end{array}$ & $\begin{array}{c}\text { cases } \\
3 \\
1 \\
2 \\
1 \\
2 \\
1 \\
1\end{array}$ & $\begin{array}{c}\text { cases } \\
5 \\
3 \\
3 \\
1 \\
1 \\
\\
1 \\
2 \\
1\end{array}$ & $\begin{array}{c}\text { cases } \\
3 \\
1 \\
1\end{array}$ & $\begin{array}{c}\text { cases } \\
3 \\
1\end{array}$ & $\begin{array}{c}\text { cases } \\
4 \\
1\end{array}$ & \begin{tabular}{|c} 
cases \\
19 \\
5 \\
7 \\
2 \\
5 \\
4 \\
2 \\
2 \\
3 \\
1
\end{tabular} & $\begin{array}{c}\text { cases } \\
1 \\
1 \\
1 \\
3 \\
1\end{array}$ & $\begin{array}{c}\text { cases } \\
2 \\
3 \\
1 \\
1 \\
2 \\
1 \\
1\end{array}$ & $\begin{array}{c}\text { cases } \\
\\
5 \\
3 \\
3 \\
2\end{array}$ & $\begin{array}{c}\text { cases } \\
4 \\
1\end{array}$ & $\begin{array}{c}\text { cases } \\
2 \\
1 \\
1\end{array}$ & $\begin{array}{c}\text { cases } \\
1 \\
3 \\
1 \\
\\
1\end{array}$ & \begin{tabular}{|c} 
cases \\
1 \\
16 \\
7 \\
7 \\
4 \\
4 \\
3 \\
2 \\
3 \\
3
\end{tabular} \\
\hline Total..... & 7 & 11 & 17 & 5 & 4 & 6 & 50 & 7 & 11 & 17 & 5 & 4 & 6 & 50 \\
\hline Averages .. & 32.4 & 25.5 & 23.9 & 8.2 & 8.3 & 10.5 & & 40.7 & 33.3 & 31.8 & 15.8 & 16.5 & 15.5 & \\
\hline $\begin{array}{r}\text { Averages } 31 \\
\text { cases with } \\
\text { free acid . }\end{array}$ & 37.8 & 35.0 & 33.9 & & 27.4 & & & & & & & & & \\
\hline $\begin{array}{l}\text { Standard de } \\
\text { Standard de }\end{array}$ & $\begin{array}{l}\text { viatior } \\
\text { viatior }\end{array}$ & $\begin{array}{l}\text { of aci } \\
\text { of bas }\end{array}$ & $\begin{array}{l}\text { dity }= \\
\text { al met }\end{array}$ & $\begin{array}{l}24.4 \\
\text { bolic ra }\end{array}$ & te $=1$ & & & $\begin{array}{l}\text { Stanc } \\
\text { Stanc } \\
=\end{array}$ & $\begin{array}{l}\text { lard de } \\
\text { ard de } \\
15.1\end{array}$ & $\begin{array}{l}\text { viation } \\
\text { viation }\end{array}$ & $\begin{array}{l}\text { of acid } \\
\text { of basa }\end{array}$ & $\begin{array}{l}1 \mathrm{y}=2 \\
1 \text { metal }\end{array}$ & bolic ra & \\
\hline
\end{tabular}


It is interesting to note that the gastric secretion in exophthalmic goitre varies to some extent in the sexes. The results for free acidity are as follows:

\begin{tabular}{|c|c|c|}
\hline & $\underset{\text { per cent }}{\text { Males (18) }}$ & $\begin{array}{c}\text { Females (32) } \\
\text { per cent }\end{array}$ \\
\hline Anacidity. . & $\ldots 50.0$ & 31.3 \\
\hline & $\ldots 11.1$ & 31.3 \\
\hline Normal acidits &. .22 .2 & 34.3 \\
\hline Hyperacidity. & $\ldots 16.7$ & 3.1 \\
\hline
\end{tabular}

It is obvious that males have more of achlorhydria but also of hyperchlorhydria. That these results are significant and not due to chance may be verified to some degree by application of the chi-square test. Thus it is found that the odds are 10 to 1 against the occurrence of such results on the basis of chance alone. These differences in the sexes are unlike those found by us for normal people. The latter show a slightly increased incidence of hypoacidity among females and of hyperacidity among males. The differences existing in the exophthalmic goitre patients may be explained partly by the inequality in the severity of the disease. The average basal metabolic rate of the male patients was plus 52.0 per cent and of the female patients plus 42.4 per cent. Since the incidence of achlorhydria, as shown below, probably varies with the level of metabolism, then it is to be expected that males should have a higher incidence of achlorhydria. The higher incidence of hyperchlorhydria, however, appears to be paradoxical.

\section{Achlorhydria}

As indicated previously, of the 50 patients with exophthalmic goitre studied, 19 or 38 per cent showed achlorhydria after stimulation with histamine. This percentage becomes all the more significant when compared with the expected result based on normals. The assumption of a general depression of acidity in exophthalmic goitre will not entirely explain this high value. Consequently, it is likely that other factors play a rôle in the causation of achlorhydria.

Unlike the group which secretes free acid, the achlorhydria group shows definite correlations with some of the factors studied. Age, red blood cell count level, hemoglobin content and basal metabolic rate are more or less definitely related to the incidence of anacidity. These relationships are shown graphically in Figures $4 a$ and $4 b$. We see that 8 of the 19 patients showing achlorhydria were 40 years of age or more. The incidence of achlorhydria for this age group was 47 per cent, whereas for those under 40 years it was 33 per cent. Of the 16 patients with red blood cell counts under 4.75 million, achlorhydria was present in 56 per cent, whereas of the 34 patients with counts of 4.75 million and over it was present in 29 per cent. The percentages for the 25 patients with hemoglobin values under 75 and the 25 patients with values of 75 per cent and over were 48 and 28 respectively. Similarly, 67 per cent of the 15 
patients with metabolisms of plus 50 or more showed achlorhydria and only 26 per cent of the remainder under plus 50 showed this.

The above results must be interpreted with caution. Their significance can be determined to some extent by means of their correlation

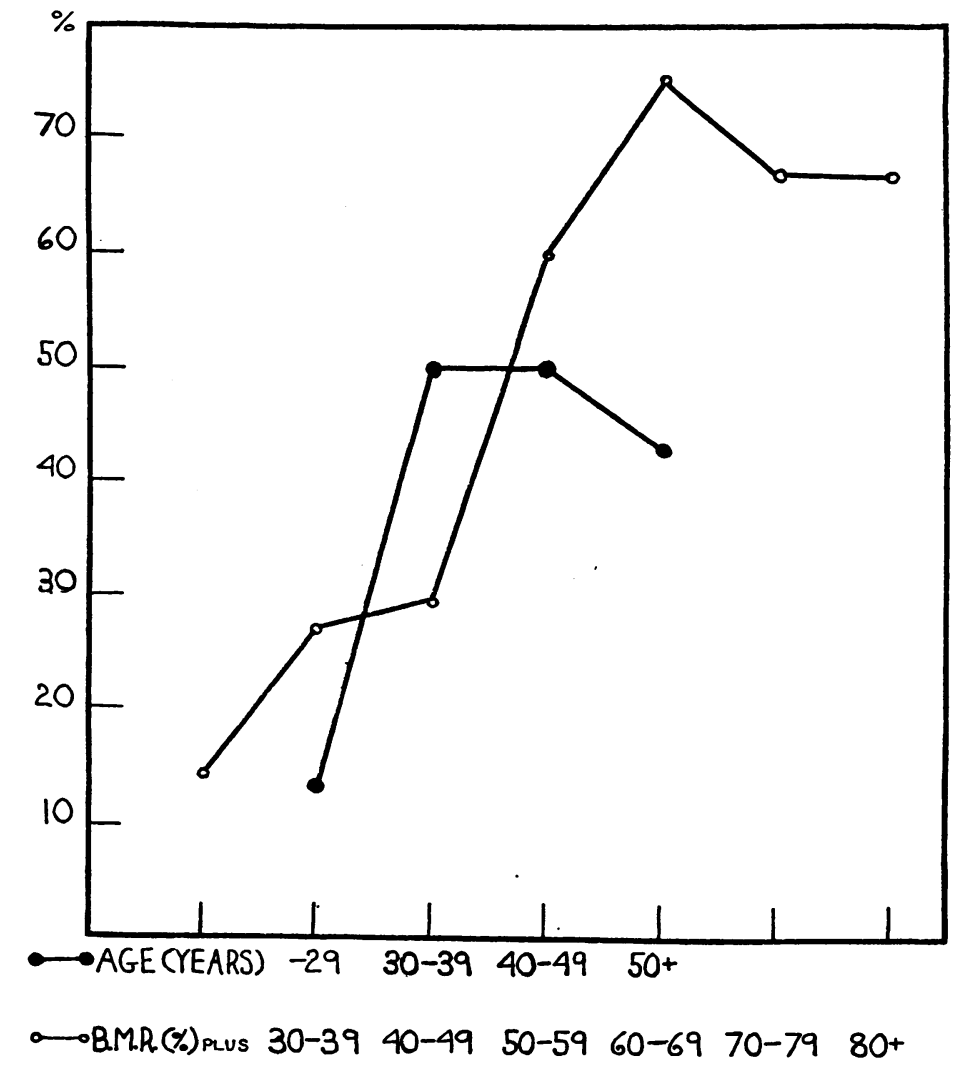

Fig. 4a. The Percentage Incidence of Achlorhydria in Exophthalmic Goitre in Relation to Age and Basal Metabolism

coefficients. This has been done by the Rank-Difference Method and the results listed in Table III. They indicate that there are high degrees of

\section{TABLE III}

The correlation between the incidence of achlorhydria in exophthalmic goitre and the factors of age, red blood cell count, hemoglobin and level of basal metabolic rate

\begin{tabular}{|c|c|c|c|}
\hline Correlation of achlorhydria with: & $\begin{array}{l}\text { Coefficient of } \\
\text { correlation }\end{array}$ & Probable error & $\frac{\text { Coefficient }}{\text { Probable error }}$ \\
\hline 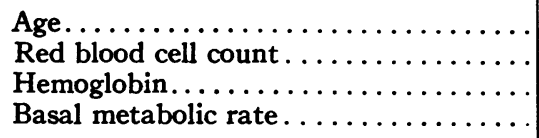 & $\begin{array}{l}+0.69 \\
-0.56 \\
-0.54 \\
+0.93\end{array}$ & $\begin{array}{l} \pm 0.125 \\
\pm 0.198 \\
\pm 0.158 \\
\pm 0.029\end{array}$ & $\begin{array}{r}5.5 \\
2.8 \\
3.4 \\
32.1\end{array}$ \\
\hline
\end{tabular}


correlation between the incidence of achlorhydria and age level, and achlorhydria and the level of metabolism. On the other hand, there are only probable correlations (inverse) for red blood cell count and hemoglobin, of slightly greater significance than those of the entire group. The factors of age and height of metabolism are probably independent as far as their influence on the gastric secretion is concerned because most of the patients with high metabolic rates were young.

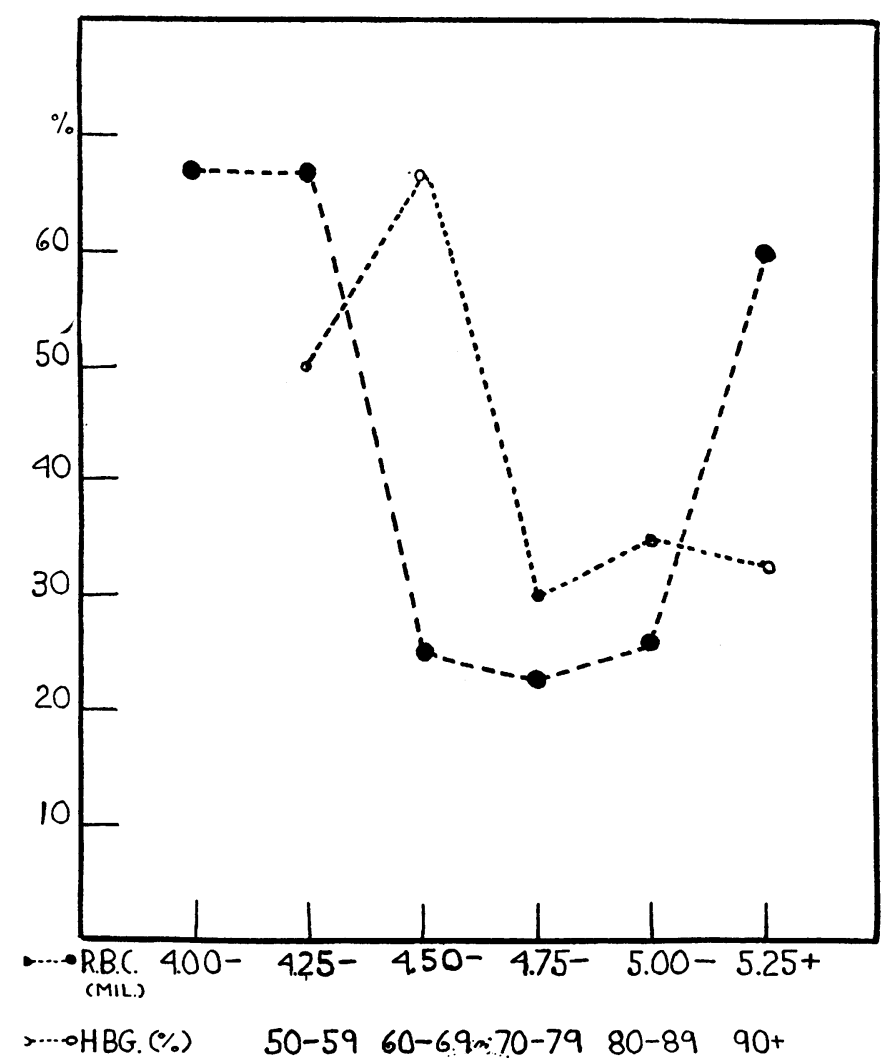

Fig. $4 b$. The Percentage Incidence of Achlorhydria in Relation to Red Blood Cell Count and Hemoglobin

\section{Myxoedema}

Seventeen patients with myxoedema were studied in the hospital. The gastric contents in all cases were examined by the same method as was used in the normal and exophthalmic goitre groups. All but two of the patients were females. The ages ranged from 36 to 73 . The results by age are recorded in Table IV. The data for total acidity were lacking in one case. 
Here also the striking results are the relatively low acidity in the group as a whole (Figures 2 and 3 ) and the high incidence of achlorhydria. As in the case of exophthalmic goitre, the results become all the more significant when compared with a normal series after correction for age distribution (Figure 5). Nine of the 17 patients, or 53 per cent, showed achlorhydria. Corrected for age distribution, the figure becomes 75 per cent compared to 15 per cent incidence in 132 normals of the same age
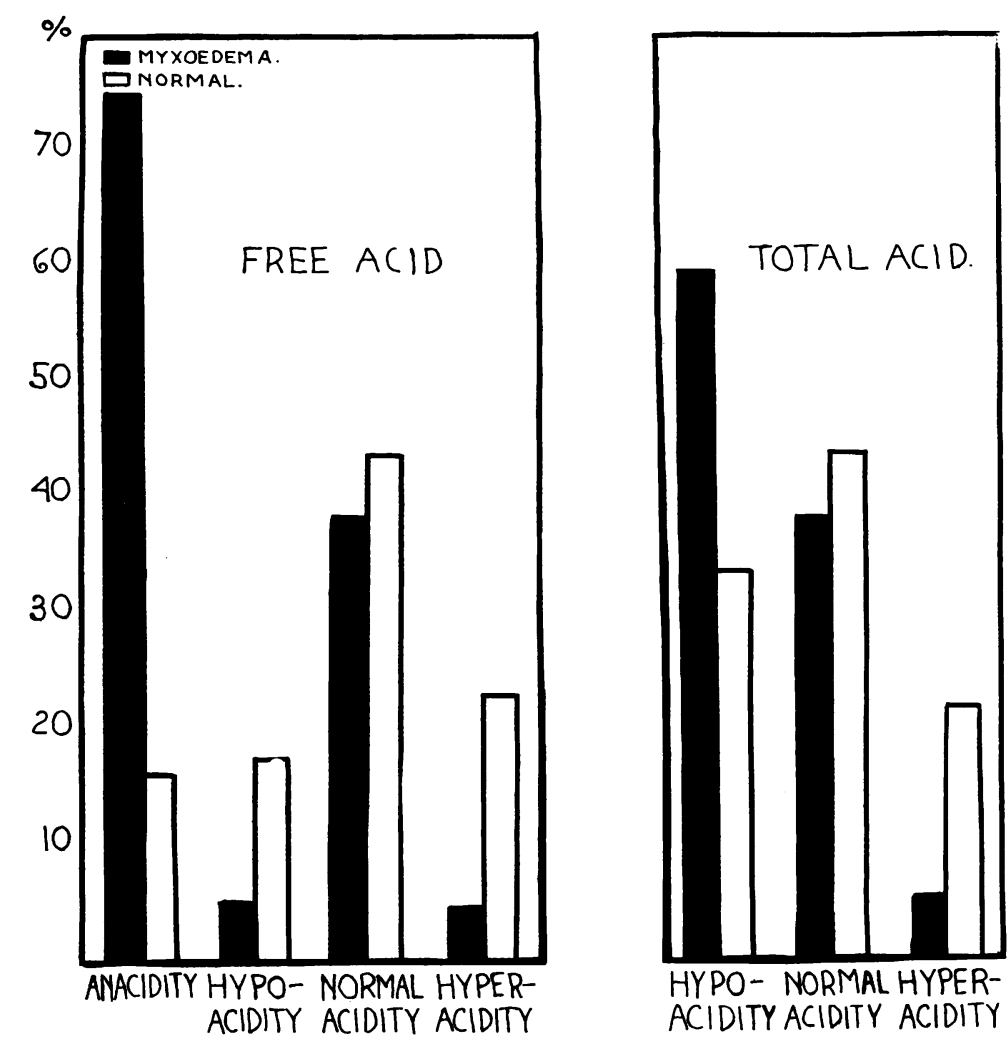

Fig. 5. The Percentage Incidence of the Various Degrees of Acidity of 132 Normal Patients Aged 40 and Over and 17 Patients (16 for Total Acid) with Myxoedema, Corrected for Differences in Age Distribution.

groups. Similarly, the corrected incidence of hyperchlorhydria (free acid) is 4.8 per cent against the normal of 23.5 per cent. The other degrees of acidity are also lower than normal, but not to the same extent. The correction for sex distribution makes the result for the incidence of achlorhydria 67 per cent, but does not alter the other figures significantly.

This brings up the same problem as already discussed in dealing with exophthalmic goitre, namely: what factors, besides general depression of 
gastric secretion, operate in these cases to cause achlorhydria? That such factors do exist must be inferred from the high incidence of achlorhydria.

The acidity of myxoedema has also been correlated with various factors such as age (Table IV), red blood cell count, hemoglobin, and

TABLE IV

Distribution by age of the free and total acidity in patients with myxoedema

\begin{tabular}{|c|c|c|c|c|c|c|c|c|c|c|}
\hline \multirow{3}{*}{ Cc. $0.1 \mathrm{~N} \mathrm{HCl}$} & \multicolumn{5}{|c|}{ Free acidity } & \multicolumn{5}{|c|}{ Total acidity } \\
\hline & \multicolumn{4}{|c|}{ Age (years) } & \multirow{2}{*}{ Total } & \multicolumn{4}{|c|}{ Age (years) } & \multirow{2}{*}{ Total } \\
\hline & -49 & $50-59$ & $60-69$ & $70+$ & & -49 & $50-59$ & $60-69$ & $70+$ & \\
\hline 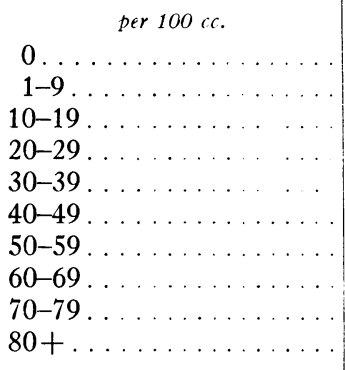 & $\begin{array}{l}1 \\
2 \\
1\end{array}$ & $\begin{array}{c}\text { cases } \\
2\end{array}$ & $\begin{array}{c}\text { cases } \\
1 \\
1\end{array}$ & $\begin{array}{c}\text { cases } \\
2\end{array}$ & $\begin{array}{c}\text { cases } \\
9 \\
1 \\
1 \\
2 \\
1 \\
2 \\
1\end{array}$ & $\begin{array}{c}\text { cases } \\
3 \\
2 \\
1 \\
1 \\
1 \\
1\end{array}$ & $\begin{array}{c}\text { cases } \\
1\end{array}$ & $\begin{array}{c}\text { cases } \\
1 \\
1\end{array}$ & $\begin{array}{c}\text { cases } \\
1 \\
1\end{array}$ & $\begin{array}{c}\text { cases } \\
1 \\
5 \\
3 \\
\\
1 \\
2 \\
2 \\
1 \\
1\end{array}$ \\
\hline Total ............... & 9 & 3 & 2 & 3 & 17 & 9 & $2^{*}$ & 2 & 3 & 16 \\
\hline Averagcs............ & 27.6 & 10.3 & 12.5 & 17.3 & & 35.9 & 21.5 & 16.5 & 27.7 & \\
\hline $\begin{array}{l}\text { Standard deviation of age } \\
\text { Standard deviation of free }\end{array}$ & acidi & $\begin{aligned} & =1 \\
\mathrm{ty} & =2\end{aligned}$ & $\begin{array}{l}10.8 \\
27.8\end{array}$ & & & $\begin{array}{l}\text { Stand } \\
=1 \\
\text { Stand } \\
\text { acid }\end{array}$ & $\begin{array}{l}\text { ard de } \\
10.8 \\
\text { ard d } \\
\text { lity = }\end{array}$ & $\begin{array}{l}\text { eviatio } \\
\text { deviati } \\
29.1\end{array}$ & ion of & total \\
\hline
\end{tabular}

* One patient in this group was found to have no free acid following histamine, but total acidity was not recorded.

basal metabolic rate. There is obviously no correlation between age and incidence of achlorhydria. In the case of red blood cells and hemoglobin, the findings are a little different. Nine of the 17 patients had counts below 4 million red blood cells and three below 3 million. The average free acidity of the 9 patients with counts under 4 million was $20.2 \mathrm{cc}$. of $0.1 \mathrm{~N}$ hydrochloric acid, and of the 8 patients with counts over 4 million it was $21.8 \mathrm{cc}$., values which indicate that the red blood cell level on the whole is not related to acidity. On the other hand, of the 9 patients with achlorhydria, 6 had counts below 4 million and 2 below 2 million cells. Of the 8 cases showing free acid, only 3 had counts below 4 million. Also, the incidence of achlorhydria in the cases with counts under 4 million cells was 67 per cent against 38 per cent in the cases with counts of 4 
million cells and over. It seems, therefore, that low red blood cell counts are more frequent among patients with achlorhydria than among those with free acid. In the case of hemoglobin, the average acidity is more closely related to the level of hemoglobin. Twelve cases with hemoglobin values under 75 per cent averaged $14.8 \mathrm{cc}$. of $0.1 \mathrm{~N}$ free acid, whereas the remaining five averaged $35.8 \mathrm{cc}$. High values of acidity occurred less often with low hemoglobin figures than with high ones. Eight of the 9 cases with achlorhydria had hemoglobin values below 75 per cent. Of the 12 cases with hemoglobin values under 75 per cent, 8 had no free acid, whereas only one of the 5 remaining cases had anacidity.

The effect of metabolism on the acidity of the gastric juice is also definite but slight. The average free acidity of 11 patients with metabolic rates greater than minus 30 was $13.1 \mathrm{cc}$. of $0.1 \mathrm{~N}$ acid and of the 6 remaining patients was $35.3 \mathrm{cc}$. Similarly, the 3 patients in the group minus 10 to minus 19 all had achlorhydria, whereas the three highest acidities occurred in the group of minus 30 to minus 39 . These results are contrary to what might be expected. Since there is a general depression in the gastric secretion in myxoedema, it is only natural to expect that the more severe the disease, the greater the depression. Here also is evidence that factors other than depression alone play a rôle in producing the changes in the gastric secretion.

These relationships may be further clarified by treating the data mathematically. In Table $\mathrm{V}$ are listed the coefficients of correlation

TABLE V

The correlation between acidity in myxoedema and age, red blood cell count, hemoglobin and basal metabolic rate

\begin{tabular}{|c|c|c|c|c|c|c|}
\hline \multirow[b]{2}{*}{$\begin{array}{l}\text { Correlation of acidity } \\
\text { with: }\end{array}$} & \multicolumn{3}{|c|}{ Free acidity } & \multicolumn{3}{|c|}{ Total acidity } \\
\hline & $\begin{array}{l}\text { Coeffi- } \\
\text { cient of } \\
\text { correla- } \\
\text { tion }\end{array}$ & $\begin{array}{c}\text { Probable } \\
\text { error }\end{array}$ & $\frac{\text { Coefficient }}{\text { Probable error }}$ & $\begin{array}{l}\text { Coeffi- } \\
\text { cient of } \\
\text { correla- } \\
\text { tion }\end{array}$ & $\begin{array}{c}\begin{array}{c}\text { Probable } \\
\text { error }\end{array} \\
\text {. }\end{array}$ & $\frac{\text { Coefficient }}{\text { Probable error }}$ \\
\hline Age $\ldots \ldots \ldots \ldots \ldots$ & -0.16 & \pm 0.167 & 1.0 & -0.17 & \pm 0.171 & 1.0 \\
\hline Red blood cell count & +0.26 & \pm 0.160 & 1.6 & +0.077 & \pm 0.176 & 0.4 \\
\hline Hemoglobin . . . . . . & +0.36 & \pm 0.149 & 2.4 & +0.22 & \pm 0.168 & 1.3 \\
\hline Basal metabolic rate & +0.27 & \pm 0.159 & 1.7 & +0.35 & \pm 0.155 & 2.3 \\
\hline
\end{tabular}

between acidity and the above-mentioned factors. These figures are more or less confirmatory in that they indicate probable slight correlations but no certain correlations. It must be remembered that results based on 17 cases are to be interpreted with caution. Definite conclusions regarding the relationship between gastric acidity and age, red blood cell count, hemoglobin and basal metabolic rate cannot be drawn until many more cases of myxoedema have been studied. 


\section{DISCUSSION}

The lowering of the acidity of the gastric secretion in exophthalmic goitre and in myxedema is definite and clearcut. On the basis of experimental findings quoted previously, these results are certainly unexpected. If the activity of the thyroid alone played the major rôle, then there should be found hypoacidity in exophthalmic goitre and hyperacidity in myxoedema. Consequently, we must infer that probably other factors also play a rôle in affecting the gastric secretion in these conditions.

As already mentioned, the data indicate that depression alone of a previously normal acidity will not account for the high incidence of achlorhydria in these two diseases. In general, the average acidity is about half the normal value, whereas the incidence of achlorhydria is fourfold and fivefold that of normal in exophthalmic goitre and myxoedema respectively. The possibility of a threshold phenomenon must be considered, i.e., depression of the gastric secretion occurs up to a point beyond which achlorhydria will result. This threshold, if such there be, must vary with different people. Lewit (8) suggests an explanation of achlorhydria in exophthalmic goitre on an anamical basis. The gastric mucosa is functionally incompetent as a result of diffuse lymphocytic infiltration. Consequently, it is very susceptible to traumatic influences which may lead to atrophy. One might attempt to explain the achlorhydria on the basis of regurgitation of alkaline duodenal contents into the stomach. If this were true, then the total acidities would be relatively high, and biletinged gastric contents would be frequent. Our analyses, however, showed that the total acidities in the cases of achlorhydria were low. Bile-tinged secretion was mentioned in 8 cases of exophthalmic goitre and in 2 cases of myxoedema. Still another explanation is that the achlorhydria and these two diseases have predisposing constitutional factors in common.

The question naturally arises whether the achlorhydria is permanent or not. If constitutional, the achlorhydria would be expected to persist. If acquired as a result of the disease, then it still might be permanent because of damage to the acid secretory mechanism of the stomach. The findings of Lewit (8) that 10 of 17 autopsied patients showed gross atrophy of the gastric mucosa would support this idea if it were not for the fact that postmortem changes make such observations on the stomach extremely unreliable.

Further investigation of this problem is necessary. We have at present only indirect evidence on this point. Although most authors feel that the combination of exophthalmic goitre and pernicious anemia in the same person is extremely rare, Meulengracht (21) found 8 cases out of a total of 151 pernicious anemia patients, associated with exophthalmic goitre. Most of them developed the anemia subsequent to the thyroid disease and achlorhydria was known to be present for several years before 
the blood picture. It would seem that in some cases of exophthalmic goitre, at least, achlorhydria does persist. In a recent communication (22), we reported on the coexistence of myxoedema and pernicious anemia in 5 cases. In one of these (Case 2) thyroid medication for myxoedema was carried out for about 7 years before the onset of anemia. This finding suggests that in myxoedema also the achlorhydria may persist.

The knowledge of what the gastric secretion shows in exophthalmic goitre and myxoedema is of practical as well as of theoretical interest. As a diagnostic procedure, the finding of achlorhydria should focus one's attention on the possibility of the coexistence of pernicious anemia. Furthermore, since the patients with achlorhydria have a definite tendency to anemia, the knowledge of its presence should be useful in planning the proper course to prevent further development of the anemia or possible occurrence of the pernicious type.

\section{CONCLUSIONS}

1. In patients with exophthalmic goitre and myxoedema, there is a definite lowering of the gastric acidity to about half its normal value.

2. The incidence of achlorhydria in exophthalmic goitre is 38 per cent and in myxoedema is $\mathbf{5 3}$ per cent. Corrected for the age distribution of a normal group, the incidence is 46 per cent and 75 per cent respectively.

3. The frequency of achlorhydria is out of proportion to the depression in the average acidities and suggests that other factors are also important in its causation. There is perhaps a threshold of gastric secretion, and if the secretion is depressed beyond it, anacidity results.

4. In exophthalmic goitre, there is no definite correlation between gastric acidity and such factors as age, red blood cell count, hemoglobin and level of basal metabolism. On the other hand, there is a high degree of correlation between the incidence of achlorhydria and age and basal metabolic rate and a probable inverse correlation between the incidence of achlorhydria and red blood cell count and hemoglobin. There is also a higher incidence of achlorhydria and hyperchlorhydria among males than among females.

5. In myxoedema, there is an unusual tendency to anemia among patients with achlorhydria.

6. There is indirect evidence that achlorhydria may persist in some cases at least after the primary condition has been cured.

7. The knowledge of the gastric secretion in an individual case may be of practical importance in prevention of the development of anemia. 


\section{BIBLIOGRAPHY}

1. King, J. H., Med. Clin. N. Am., 1919, ii, 1655. Gastro-Intestinal Disturbances in Metabolic Diseases and in Diseases of the Ductless Glands.

2. Lockwood, B. C., J. Am. Med. Assoc., 1925, lxxxv, 1032. The Digestive Tract and Endocrine Function.

3. Moll, H., and Scott, R. A. M., Lancet, 1927, i, 68. Gastric Secretion in Graves' Disease.

4. Herzfeld, E., Deutsche med. Wchnschr., 1923, xlix, 1436. Zur Magensekretion bei Morbus Basedowi.

5. Keefer, C. S., and Bloomfield, A. L., Bull. Johns Hopkins Hosp., 1926, xxxix, 304. The Significance of Gastric Anacidity.

6. Moore, H., Brit. Med. J., 1930, i, 698. Significance of Achlorhydria.

7. Neilson, C. H., J. Am. Med. Assoc., 1914, 1xii, 434. Some Points in the Treatment of Hyperacidity.

8. Lewit, S. G., Z.tschr. f. klin. Med., 1925, cii, 440. Schilddrüse und Magensekretion.

9. Badylkes, S. O., Arch. f. Verdauungskr., 1925, xxxiv, 105. Klinischphysiologische Beobachtungen über den Einfluss einiger Hormone auf die Magensekretion (experimentelle Lntersuchungen).

10. Boenheim, F., Arch. f. Verdauungskr., 1920, xxvi, 74 . Über den Einfluss von Blutdrüsen-Extrakten auf die Magensekretion.

11. Katz, J., Med. Rec., 1920, xcrii, 916. Deficient Thyroid Secretion as an Etiologic Factor in Gastric and Duodenal Ulcers and in Hyperacid Conditions.

12. Lery, M. D., New Orleans Med. and Surg. J., 1929, lxxxi, 487. Endocrine Influence on Gastric Secretion with Special Reference to Hypothyroidism.

13. Hutton, J. H., Illinois Med. J., 1922, xlii, 337. Effects of Hypothyroidism.

14. Sturgis, C. C., Med. Clin. N. Am., 1922, v, 1251. A Clinical Study of Myxedema with Observations of the Basal Metabolism.

15. Hardt, L. L. J., Am. J. Physiol., 1916, xl, 314. Contributions to the Physiology of the Stomach. XXXIII. The Secretion of Gastric Juice in Cases of Gastric and Duodenal Ulcers.

16. Truesdell, C., Am. J. Physiol., 1926, lxxvi, 20. The Effect of Feeding Thyroid Extract on Gastric Secretion.

17. Chang, H. C., and Sloan, J. H., Am. J. Physiol., 1927, 1xxx, 732. Influence of Experimental Hypothyroidism upon Gastric Secretion.

18. Rogers, J., Rahe, J. M., and Ablahadian, E., Am. J. Physiol., 1919, xlviii, 79. The Stimulation and Inhibition of the Gastric Secretion which Follows the Subcutaneous Administration of Certain Organ Extracts.

19. Lerman, J., Pierce, F. D., and Brogan, A. J., J. Clin. Invest., 1932, xi, 155. Gastric Acidity in Normal Individuals.

20. Bloomfield, A. L., and Keefer, C. S., J. Clin. Invest., 1928, v, 285. Gastric Acidity: Relation to Various Factors Such as Age and Physical Fitness.

21. Meulengracht, E., Klin. Wchnschr., 1929, viii, 18. Morbus Basedowii und Perniziöse Anämie.

22. Means, J. H., Lerman, J., and Castle, IV. B., New Eng. J. Med., 1931, cciv, 243. The Coexistence of Myxoedema and Pernicious Anemia. 